\title{
Education Transformation in the Arctic Region of the Republic Of Sakha (Yakutia) Under the Impact of New Information Technologies in Modern Conditions
}

\section{Transformación educativa en la región ártica de la República de Sakha (Yakutia) bajo el impacto de las nuevas tecnologías de la información en las condiciones modernas}

\author{
Zoya S. Zhirkova* \\ Ammosov, North-Eastern Federal University, Yakutsk, Russian Federation. \\ ORCID: http://orcid.org/0000-0003-2815-7061
}

Alla G. Kornilova

Ammosov North-Eastern Federal University, Yakutsk, Russian Federation. ORCID: https://orcid.org/0000-0001-6790-3085

\section{Lyudmila I. Amanbaeva}

Ammosov, North-Eastern Federal University, Yakutsk, Russian Federation. ORCID: http://orcid.org/0000-0002-7467-7319

\section{Iurii V. Kornilov}

Ammosov, North-Eastern Federal University, Yakutsk, Russian Federation. ORCID: http://orcid.org/0000-0002-5801-2616

\section{Lyubov D. Unarova}

Higher School of Music of the Sakha Republic (Yakutia) (Institute) named after V. A. Bosikov, Yakutsk, Russian Federation.

ORCID: http://orcid.org/0000-0003-2565-3860

Received 07-07-20 Revised 07-25-20 Accepted 09-13-20 On line 09-23-20

*Correspondence

Email: z_zhirkova@list.ru
Cite as:

Zhirkova, Z.S., Kornilova, A.G., Amanbaeva, L.I., Kornilov, I.V., \& Unarova, L.D. (2020). Education Transformation in the Arctic Region of the Republic Of Sakha (Yakutia) Under the Impact of New Information Technologies in Modern Conditions. Propósitos y Representaciones, 8 (SPE3), e722. Doi: http://dx.doi.org/10.20511/pyr2020.v8nSPE3.722 


\section{Summary}

Currently, education is considered as a multidimensional and comprehensive process of personality formation. Among other things, it contributes to the development of basic abilities such as critical thinking, problem solving ability, networking, adaptability, and initiative. Learning is continuous and widely accessible, both with regard to adaption and personalization. Nowadays, teachers are required to search for innovative technologies and techniques providing qualitative acquirement of the material and the development of key subject competencies. The objective of the study is to introduce information and communication technologies (ICT) in education. The authors use the methods of testing, questionnaire, study of documents, and reflection. The survey involves 312 fulltime and part-time students of M. K. Ammosov North-Eastern Federal University (NEFU), among which 178 people represent the Arctic Region. The survey's results are introduced in Tables 1 and 2. The results of the study are positive, with quantitative and qualitative indicators confirming the purpose of the study.

Keywords: Transformation; Education; Arctic Region, Information Technology; Socialization.

\section{Resumen}

Actualmente, la educación es considerada como un proceso multidimensional e integral de formación de la personalidad. Entre otras cosas, contribuye al desarrollo de habilidades básicas como pensamiento crítico, capacidad de resolución de problemas, trabajo en red, adaptabilidad e iniciativa. El aprendizaje es continuo y ampliamente accesible, tanto en lo que respecta a la adaptación como a la personalización. Hoy en día, los profesores están obligados a buscar tecnologías y técnicas innovadoras que proporcionen la adquisición cualitativa del material y el desarrollo de competencias temáticas clave. El objetivo del estudio es introducir las tecnologías de la información y la comunicación (TIC) en la educación. Los autores utilizan los métodos de prueba, cuestionario, estudio de documentos y reflexión. La encuesta involucra a 312 estudiantes a tiempo completo y a tiempo parcial de la Universidad Federal del Nordeste M. K. Ammosov (NEFU), entre los cuales 178 personas representan la región ártica. Los resultados de la encuesta se presentan en las Tablas 1 y 2. Los resultados del estudio son positivos, con indicadores cuantitativos y cualitativos que confirman el propósito del estudio.

Palabra clave: Transformación; Educación; Región Ártica, Tecnología de la Información; Socialización.

\section{Introduction}

Currently, education is widely regarded as a multidimensional and comprehensive process of personality formation. In addition to accomplishing other objectives, education contributes to the development of such basic abilities as critical thinking, problem solving ability, networking, adaptability, initiative, and entrepreneurship. In terms of both adaptation and personalization of the education system, learning is continuous and widely accessible.

The purpose of education is to transmit the entire cycle of the reproduction of culture and people's activity in the educational space of the region. This, in turn, is reflected in the educational content, structural coexistence and interaction of various educational systems along with their components, and educational events. In this regard, it acts as a form of translation of culture, traditions, and social experience of previous generations to each subsequent one. Today, as regards the transition to a competency-based education, teachers are faced with the task of finding innovative technologies and techniques that contribute to the qualitative assimilation of material as well as the formation of key subject competencies 
Education is a multi-layered process containing multifarious elements of various spheres, namely: problematic and programmed training, training based on the theory of the gradual formation of mental activities (Galperin, 2008; Talyzina, 2011), pedagogical technology for educational process projecting, as well as new information technologies for education (Beshenkov, 2014; Robert, 2014; Robert, 2017). Elements of various approaches to education make it possible to use their advantages for each stage of the educational system, for each specific educational situation in accordance with students and teachers' abilities and individual psychological characteristics (Barakhsanova, 2018; Vlasova, 2019; Prokopyev, 2017).

All the above mentioned aspects form the basis for identifying the first results of the education modernization, namely: the development of the models for improving the education system at the regional level, the implementation of which would allow us to solve the problem of the substantial improvement of education system and its correspondence to modern requirements:

- Values motivate and involve;

- Pedagogy theoretically substantiates and launches an educational process that develops key abilities such as critical thinking, problem solving, networking, flexibility, adaptability, and initiative;

- Forms of training: interaction of various forms of work, optimization of the educational process, individualization of the educational process. The key form is e-learning, which is characterized by flexibility, adaptability, individualization, interactivity, and deep reflection;

- Educational resource is characterized by the provision with pedagogical personnel. Due to the changing of the teachers' role in the educational process, learning is determined by redundancy and variability, interactivity, multimedia, a variety of presentation forms, control and evaluation materials;

- Content is focused on practice; motivation is rather internal than external;

- Technology supports a constantly updated educational system.

Therefore, modern education solves two main tasks:

- It helps the developing personality to overcome instability by forming a systemic and integrated world view;

- Contributes to the adaptation to instability.

These two tasks are multidirectional:

- The first one contributes to a personality self-realization in the context of a strategic perspective;

- The second task deals with tactical perspective.

According to new educational paradigm, various models for education improvement can be developed. The update of the educational content and the implementation of innovative technologies contribute to the integration of all means of the world investigation, as well as selfeducation and availability of various information systems that determine personal orientation of the educational process.

The purpose of the research is to substantiate and develop theoretical and methodological foundations of education transformation in the Arctic Region of the Republic of Sakha (Yakutia) under the impact of new information technologies in modern conditions. The objective of the study is to provide the application of information and communication technologies in educational process. 
Yakutia is the largest constituent entity of the Russian Federation (3103.2 thousand sq. $\mathrm{km}$.) and it remains one of the most isolated and inaccessible regions of Russia. The natural and climatic conditions of the Republic of Sakha (Yakutia) are extreme. It is the coldest inhabited region of the planet. The share of general education organizations in remote places is $78 \%$. The way of living and economy require special approaches, technologies and regulation, taking into account the conditions of each natural and climatic zone.

Informatization is an important factor of the education system development. The Government of the Republic of Sakha (Yakutia) adopted a republican target informatization program in August 21, 2001 No. 430 "Development of Information Resources, Information Systems, Technologies and Means of their Support in the Republic of Sakha (Yakutia) until 2005". The present program provides a single information environment in the region for the access of all government bodies, legal entities and citizens to state information resources and any open information on the Republic and Russia (Neustroev, 2012; Kornilov, Nikolayeva, Golikov, Gosudarev, 2019; Kukarenko, Zashikhina, 2017).

The Ministry of Education of the Republic of Sakha (Yakutia) has developed a project "Program for the Introduction of New Information Technologies at All Levels of the Education System", compiled information maps of the existing network, connecting educational institutions to the Internet, training and retraining the teaching staff.

The transformation of the modern world determines cultural processes. Therefore, traditional education systems cannot ensure the synchronous reproduction of new knowledge systems. The transition to a new education system should include the following components of education: a value-semantic component; communicative and active; cognitive and instrumental. Being developed in the framework of pedagogical programs, these components are implemented in training sessions. Judgment and attitude are knowledge units, which acquire personal meaning of the actions being formed, allowing the individual to be involved in the activity, since there is always activity between learning and development.

\section{Material and Methods}

An analysis of the research works of foreign and Russian authors shows that the development and substantiation of theoretical and methodological foundations for the transformation of education in the Arctic Region of the Republic of Sakha (Yakutia) under the influence of new information technologies in modern conditions are especially relevant during the pandemic and acquire new qualitative characteristics.

The scientific discovery of the Arctic civilization phenomenon allows us to identify new prospects for the application of new information technologies in the education of the Arctic Region. These prospects must be based on historically established complexes of the rights of indigenous peoples in the field of education and on the trend of global sustainable development. Recently, these aspects are of particular concern of Russian and foreign researchers, namely Heininen, Fondahl, Filippova, Mack, Koptseva, Kirko, Robbeck, Todal, Zhirkova, Vinokurova, Yakovets. The authors declare, that the values of the Arctic civilization should be preserved and distributed in the scientific, educational, informational and geopolitical directions through the dialogue of the modern civilizations.

The authors of the present research followed Altbach and Knight's ideas on the internationalization of higher education, Olofsson and Price's concept of teaching using technology in higher education, Yot-Domínguez and Marcelo's understanding of conceptual change and development in practice, and Akbar's reasoning on self-regulated teaching at university using digital technologies, which influence the development of the pedagogical 
practice in the High School. It is also worth highlighting the works by Risto E.J. Penttila on student and research mobility in the European Arctic.

Significant contribution was made to the theories of information society development and the informatization of social and educational environment by Afanasyev, Bespalko, Robert, Beshenkov, Minzaeva, Kolin, and Polat.

It is worth emphasizing the works on substantiation and analysis of the organizational and pedagogical conditions of education informatization in the Republic of Sakha (Yakutia) by Barakhsanova, Lukina, Burnashev, Prokopyev, Kornilov, Sorochinsky, etc. The experts have identified theoretical and methodological aspects of the adaptation of new information technologies and teaching techniques to the educational process, and the subsequent transformation of the pedagogical system. Practical experience and theoretical research show that effective development and implementation of educational processes at all levels of education in modern information and educational environments require the transformation of existing pedagogical system in the context of the development of information and communication technologies. The main components of the pedagogical system, including pedagogical tasks and relevant pedagogical technologies, as well as the pedagogical process are considered in the context of electronic educational environment, i.e., information, interactive, multimedia, information and educational (Eichelberger, 2015; Kornilov, Danilov, Kornilova, Kovtun, 2017; Kowalski, 2015).

Despite the dynamic educational research, the use of new information technologies and teaching techniques in the educational process, psychological and pedagogical aspects of the effective use of information and communication technology (ICT), its effectiveness and restrictions, estimated positive and negative consequences for personality development are as yet little understood.

The main idea of the present study is to analyze the impact of new information technologies on the education transformation in the Arctic Region of the Republic of Sakha (Yakutia) in terms of the pandemic. In this regard, educational work at NEFU has been modified into distance learning, i.e., all the students of NEFU were studying remotely from their places of residence (in uluses). It should be noted that the quality of the Internet connection in rural areas of the Republic of Sakha (Yakutia) differs significantly.

North-Eastern Federal University is a training center for specialists in the socioeconomic development of the Republic of Sakha (Yakutia). The authors of the present study conducted research on the application of ICT in the educational process. North-Eastern Federal University widely uses the Moodle learning system, which is characterized by a competent structure, flexibility, and various functions for distance learning. In addition, it is very easy to use. Moodle is modern software that allows teachers and students to interact online effectively using the unique functions of the Internet and based on maximum information support including electronic information resources, educational and methodological complexes of a new generation, mathematical models for practical work performed in 3D graphics, facility instrumentation, etc. The academic staff of the university has developed methods and forms of training that adequately reflect the didactic facilities of modern educational information technologies.

The researchers applied effective tools for collecting data that meet the requirements for measurement quality, which were adapted to students' psychological characteristics. We will focus on the criteria for the survey of students majoring in pedagogy and psychology at the Department of Social Pedagogy of the Pedagogical Institute of NEFU. The authors of the present research have analyzed the results of the students' distance learning on the Moodle platform. The following aspects were investigated: the use of relevant computer programs for education, the use 
of software tools that ensure students' effective independent work, all possible forms of knowledge transfer, and the assessment of the quality of knowledge mastery by means of a special system.

The following aspects of the educational process on the Moodle Platform have been assessed:

- The clarity of its organization;

- The compliance of basic parameters with norms and standards;

- The feasibility of the goals. Ensuring the students' internal acceptance of the work goal, i.e., an understanding of its necessity and the result expected;

- Stability and faultlessness of the main processes and actions of the students and the trainees; comfort;

- Accuracy of implementation of plans, programs, schedules, social and psychological

- The loads that are safe for the trainees' health;

-Reflection, due to which a person constantly examines the foundations of thinking;

- The compliance of the distance learning with educational programs of the Federal State Educational Standard 3+ (FSES 3+) by means of the questionnaires developed by the teachers of the university and necessary conditions for achieving positive results that contribute to its development and activation.

\section{Results}

The analysis of the implementation of the educational program on the Moodle platform and the obtained results are introduced in Table 1. The sample contains 84 disciplines of the FGOS $3+$.

Table 1.

Analysis of the filling in the modules on the Moodle platform by academic staff of the Department of Social Pedagogy (Sample size is 84 disciplines)

\begin{tabular}{lllr}
\hline Moodle platform & $\begin{array}{l}\text { Modules completion } \\
\text { before switching to during } \\
\text { distance learning }\end{array}$ & $\begin{array}{l}\text { learning } \\
\text { distance }\end{array}$
\end{tabular}

\begin{tabular}{lll}
\hline 1. Standard & $69-82.1 \%$ & $100 \%$ \\
2. Theoretic & $48-57.2 \%$ & $93 \%$ \\
3. Practical & $36-42.8 \%$ & $85 \%$ \\
4. Diagnostic & $27-32.1 \%$ & $72 \%$ \\
5. Methods & $42-50 \%$ & $88 \%$
\end{tabular}

The results of the analysis allow us to conclude that teachers applied distance learning irregularly or combined it with traditional teaching methods, active and interactive technologies, project method, etc. The questionnaire analysis shows that teachers are more effective in using the methods of dialogue teaching. Through dialogue, teachers can conduct interesting discussions in which students actively participate. Dialogue is regarded as a technology of the subject - subject relations, as a live feedback, and as a reflexive training of the student's dialogue with his or her inner self. In addition, the teachers actively introduce project technology, which includes a set of investigation, search, and problematic methods, which are creative by their nature. 
The survey of the development and filling in the Moodle modules by the teachers of the Department of Social Pedagogy showed that the structure and content of the educationalmethodological complex (EMC) and its electronic version (EEMC) contribute to the implementation of all the components of the educational process. The systems of normative and educational-methodical documentation, training and monitoring tools of EMC and EEMC are necessary for the effective use of basic and additional educational programs. They help to achieve educational, training, developmental, and practical goals of learning. Additionally, the switch to distance learning contributed to the intensification of different aspects of activity, such as intellectual, personal, and social. The purpose of the survey, conducted by the academic staff of the Pedagogical Institute, was to assess the development of the competencies in terms of the transmission to distance learning.

Table 2.

The development of the students' key competencies in terms of switching to a distance learning

\begin{tabular}{lll}
\hline Intensification of all levels & Development of the students' & The \\
of the educational process & personality, his or her preparation for & independent work in \\
in accordance with the & a comfortable life in the information & accordance with the \\
Moodle program & society & educational programs of \\
& & FSES 3+
\end{tabular}

1. Improvement of the - Development of different types of efficiency and quality of thinking

the learning process;

- Development of communication
skills;

2. Increase in the mobility, skills;

activity, and creativity

3. Development of the

- Development of the ability to make intersubject connections;

the best decision or offer solutions in a difficult situation;

4. Increase in the volume

- initiative and self-motivation, self-

Reports presentation.

Participation

in

discussions.

Essay.

Practical assignments.

Social project

development.

Participation in public

works.

of information and the

confidence, the ability to organize optimization of its search

public works;

5. Development of mobile

- Development of information culture feedback by means of and the ability to search, process, different tools of analyze critically and synthetize information technology information,

- Development of skills to simulate a task or situation, to apply a systematic approach for the assigned tasks solution;

Reflection.

- Development of skills to carry out experimental research activities. 
The survey involved 102 students of the Department of Social Pedagogy. The students' reflections at the end of the course were analyzed. To determine the quality of the discipline mastery, the commission considered the following criteria:

- High level - independent application of the knowledge obtained from different sources, planning, the ability to make independent statements, to express attitude clearly, and reflect independently;

- Advanced level - search for the necessary information and its analysis, application of the knowledge acquired independently from guidebooks or other sources recommended in the educational programs of FSES 3+, the ability to make statements independently or with the help of a teacher, reflection;

- Basic level - choosing the information from the suggested options, application of a prepared goal and planning the activity offered by the teacher, independent work according to the offered plan, reflection with the help of course mates;

- Critical level - weak psychological readiness for independent creative work, a superficial presentation of the material, with no personal attitude, reproductive type of activity prevails.

The expert commission, analyzing the quality of the performed independent work, noted that students have developed the following competencies of the systemic and critical thinking:

- The ability to search for information,

- Critical analysis and synthesis of information,

- Application of the systematic approach to solve the assigned tasks,

- Reasonable methods for the information search and analysis for the problem solution,

The ability to organize information in accordance with the requirements and conditions of the task.

\section{Discussion}

According to the analysis of scientific works, the authors of the present research have concluded that the application of the activity approach contributes to the improvement of such categories as motivation to participate, goal - setting, means of learning activity and their results. The personal approach takes into account the subjective characteristics of the participants in the educational process. Constructive pedagogy intensifies the learning process using active methods of information technology. The development of the educational process requires the implementation of a system approach theory, including compliance with the integrity conditions to consider the object of the research and the relationships between its individual components. In this context, it should be noted that it is impossible to create a universal standard of the educational process for all cases, revealing the significance of the information education components.

Modern information technologies provide opportunities for educational development, and enable implementation of the principles of a differentiated, individual approach to learning. It is also worth emphasizing that information technology can be applied for both in - person and distance learning, in both urban and rural schools. Technology allows us to implement global trends in education and to enter a global information space. The implementation of computer technology contributes to the improvement of self-education, educational motivation, and provides completely new opportunities for creativity, acquisition and consolidation of various professional skills (Polat, 2005; Bates, 2019; Verhoef, Broekhuizen \& Bart, 2019).

According to the research of Bespalko, Robert, Polat, Beshenkov, Minzaeva, Barakhsanova, Golovanova, Zhirkova and Kornilova, the authors of the present work have substantiated the conditions for the implementation of the didactic facilities of ICT for solving pedagogical problems of the personal and active development spheres. Focusing on professional and 
pedagogical training, the authors applied to the experience of NEFU in mastering the key competencies of students on the Moodle platform.

\section{Conclusion}

In the context of the present study, the phenomenon of "education informatization", which suggests a new area of pedagogical knowledge, was used. The authors of the study focused on new methodology, technology and practices for current educational goals and strategies, in terms of information process development and the globalization of the modern information society.

In addition, the authors have considered the issues of proper implementation of scientific, pedagogical, educational, methodological, software and technological developments devoted to the application of ICT facilities in education (in analog and digital forms).

According to the results of the survey conducted in NEFU, Moodle allows teachers and students to effectively interact online using the unique functions of the Internet, based on maximum information support, including electronic information resources, educational and methodological complexes of the new generation, 3-dimensional graphic mathematical models for practical work, facility instrumentation, etc. Additionally, methods and forms of training are developed, reflecting the didactic functions of modern information educational technologies.

The impact of new information technologies on education transformation in the Arctic Region of the Republic of Sakha (Yakutia) has been identified and described. It has been revealed that education system, which takes into account the use of ICT (analog and digital forms) in education, contributes to the development of all resources of the region, and provides prospects for socio-economic development of the Arctic Region of the Republic of Sakha (Yakutia).

Information education, as a component of education and upbringing of group subjects in the Arctic educational environment, contributes to the change of technology and practice of new goals solutions and strategies settings for the development of the educational system related to the information processes development and globalization of the modern information society.

Therefore, it has been concluded that global modern society provides the conditions for the implementation of didactic facilities of ICT for solving pedagogical problems of the development of the personal and active sphere. In their research, the authors focused on the professional and pedagogical training and appealed to the experience of NEFU in mastering the key competencies of students on the Moodle platform.

\section{References}

Akbar, M. (2016). Digital technology shaping teaching practices in higher education. Frontiers in ICT, 3,1 .

Altbach. G., Knight, J. (2007). The Internationalization of Higher Education: Motivation and Realities. Journal of Studies in International Education, 11(3/4), 290-305.

Barakhsanova, E.A., Varlamova, V.A., Vlasova, E.Z., Nikitina, E.V., Prokopyev, M.S., Myreeva, A.N. (2018). Vocational training of school teachers in Yakutia's universities through the principle of regionalization (case study of the methodology of teaching natural science to prospective teachers). Espacios, 39(20), 35.

Bates, A.W. (2019). Teaching in a Digital Age. Vancouver, B.C.: Tony Bates Associates Ltd.

Beshenkov, S.A., Shutikova, M.I., Mindzaeva, E.V. (2015). Educational risks of the modern information society and information and cognitive technologies. Computer Science and Education, 8(267), 19-21. 
Eichelberger, J. (2015). Scientific and educational partnerships in a time of international tension: the importance of university of the Arctic. Arctic dialogue in the global world. The Proceedings of Joint Science and Education Conference.

Englund, C., Olofsson, A.D., Price, L. (2017). Teaching with technology in higher education: understanding conceptual change and development in practice. Higher Education Research \& Development, 36(1), 73-87.

Fondahl, G., Filippova, V., Mack, L. (2015). Indigenous peoples in the new Arctic. In The New Arctic. Cham: Springer.

Galperin, P.Ya. (2008). Psychology as an objective science: selected pedagogical works. Voronezh: SPA "MODEK".

Heininen, L. (2015). The Arctic as a space for interdisciplinarity, sustainable development and peace. The Arctic and the North: an interdisciplinary electronic scientific journal, 4(21), 26-33.

Koptseva, N.P., Kirko, V.I. (2015). The impact of global transformations on the processes of regional and ethnic identity of indigenous peoples Siberian Arctic. Mediterranean Journal of Social Sciences, 6(3 S5), 217.

Kornilov, I.V., Danilov, D.A., Kornilova, A.G., Kovtun, T.I. (2017). Methodical approaches to implementation of electronic educational technologies in professional academic teacher training. Man in India, 97(15). 441-460.

Kornilov, I.V., Nikolayeva, A.D., Golikov, A.I., Gosudarev, I.B. (2019). Education system features in the Arctic Economic Zone of the Republic of Sakha (Yakutia) of the Russian Federation: An expert assessment. Espacios, 40(9), 1-20.

Kowalski, K. (2015). Arctic telecommunications and networking - broadband for a connected Arctic: case for a UARCTIC thematic network. Arctic dialogue in the global world. The Proceedings of Joint Science and Education Conference.

Kukarenko, N., Zashikhina, I. (2017). Internationalization the Russian Way: Modernization of the Higher Education System in Russia. In Higher education in the high north. Cham: Springer.

Neustroev, S.S. (2012). Methodological aspects of the formation of the regional system "scienceeducation-innovation". Economics and Management, 4.

Polat, E.S., Bukharkin, M.Yu., Moiseyeva, M.V., Petrov, A. E. (2005). New pedagogical and information technologies in the education system: Textbook. Moscow. Publishing Center "Academia".

Prokopyev, M.S., Barakhsanova, E.A., Vlasova, E.Z., Golikov, A.I., Burnachov, A.E., Kuzin, Z.S. (2017). Peculiarities of quality management of teachers' e-learning training in the arctic regions. Espacios, 38(55). 25.

Risto E.J. Penttila. (2014). Student and Researcher Mobility in the European Arctic. UARCTIC ANNUAL REPORT FOR 2014.

Robbek, V.A. (2007). The scientific basis for the creation of the educational system of nomadic peoples of the North. Novosibirsk: Nauka.

Robert, I.V. (2014). The theory and the methods of the informatization of education (psychological, pedagogical and technological aspects). Moscow: BINOM. Laboratory of Knowledge.

Robert, I.V., Mukhametzyanov, I.Sh., Kastornova, V.A. (2017). Information and education space: a collective monograph. Moscow: The Institute of Education Management of the Russian Academy of Education.

Talyzina, N.F. (2011). Pedagogical psychology: study guide for the student of vocational education institutions. Moscow. Izdatelskiy tsentr "Akademiya".

Todal, J. (2015). Undervisningaisamisksomførstespråkinoregeithistorisktilbakeblikk. Information and scientific publication, 3(6), 52-60.

Verhoef, P.C., Broekhuizen, T., Bart, Y., Bhattacharya, A., Qi Dong, J., Fabian, N., Haenlein, M. (n.d.). Digital transformation: A multidisciplinary reflection and research agenda. Journal of Business Research. 
Vinokurova, U.A. (2015). Indigenous peoples of Siberia: can they respond to 21 century challenges? Retrieved from: http://zpujournal.ru/zpu/contents/2015/2/Vinokurova_Indigenous-Peoples-of-Siberia

Vlasova, E.Z., Goncharova, S.V., Karpova, N.A., Ilina, T.S., Barakhsanova, E.A. (2019). Artificial intelligence for effective professional training of teachers in the Russian Federation. Espacios, 40(22).

Yakovets, Yu.V., Rastvortsev, E.E. (2017). The System of Long-Term Goals of Sustainable Development of Civilizations. Moscow: Institute of Economic Strategies.

Yot-Domínguez, C., Marcelo, C. (2017). University students' self-regulated learning using digital technologies. International Journal of Educational Technology in Higher Education, 14(1), 38 .

Zhirkova, Z.S. (2018). Circumpolar educational space of a region: monograph. St. Petersburg: Renome. 